\title{
INSTRUCTIONS TO AUTHORS
}

The Lichenologist is an international journal and welcomes papers and short communications from contributors anywhere in the world on any aspect of lichenology.

Manuscripts must be original, clearly and precisely presented in English and electronic versions submitted to The Lichenologist ScholarOne website $<$ http://mc.manuscriptcentral.com/lich $>$ following the on-screen instructions. Please note that submission must be done from The Lichenologist ScholarOne account belonging to the Corresponding Author. Authors submitting a manuscript do so on the understanding that, if it is accepted, copyright of the paper will be assigned exclusively to the publisher (see Copyright below).

Key words. Supply 3-6 key words or phrases in addition to those in the title.

Text. This must be word processed on A4 $(210 \times 297 \mathrm{~mm})$ or letter $(8.5 \times 11 \mathrm{inch})$ in double spacing with $2.5 \mathrm{~cm}$ margins all round. On all points of style concerning text and tables consult recent copies of the journal. Complete scientific names (genus, species and authority) must be cited at first mention. Thereafter the generic name may be abbreviated to the initial except at the beginning of a sentence or where the abbreviation might result in confusion with other genera. Recent issues should be consulted for layout of new species, new combinations, synonymy and lists of specimens examined. Examples of style are given below. All nomenclatural novelties must be deposited in MycoBank <http://www.mycobank.org> and the MycoBank number included after the taxon name; this is intended to minimize future confusion and make taxonomic data more widely available. A short diagnosis, in either Latin or English, should follow the MycoBank number. This should be a statement of that which in the opinion of the author distinguishes the new taxon from other taxa. The spelling of locality names in the British Isles and abroad must follow the most recent editions of maps published by the Ordnance Survey and The Times Atlas of the World, respectively.

Examples of style employed in

(a) description of new species:

Fissurina immersa B. O. Sharma,

Khadilkar \& Makhija sp. nov.

MycoBank No.: MB561855

Similis $F$. inabensis sed differt ascosporis minoribus et acido norstictico continente.

Typus: India, Karnataka, Mudigiri, 26 January 1980, P. G. Patwardhan 80.92 (AMH-holotypus).

(b) citation of described species or new combinations: Pyrenopsis furfurea (Nyl.) Th. Fr.

Bot. Notiser 1866: 58 (1866); type: Scotland, Ben Lawers, 1864, fones (H-NYL 42916-lectotype; BMisolectotype).

Pyrenopsidium terrigenum (Th. Fr.) Forss., Nova Acta R. Soc. Scient. Upsal. ser. 3, 13(6): 81 (1985).-Pyrenopsis haematopsis (Sommerf.) $\beta$. terrigena Th. Fr. in Hellbom, Öfvers K. Vetens Akad. Forh. 22(6): 478 (1865); type:
Sweden, Lule Lappmark, Skarfi, 1864, Hellbom (UPSholotype).

(c) citation of specimens examined:

Long lists of citations are discouraged. Data should be reproduced as either maps or lists containing only data essential for locating specimens and collecting sites. Complete lists, with the above format, can be deposited with appropriate Institutions, and their location noted in the text.

Selected specimens examined. British Isles: Scotland: V.C.96, Easterness: Abernethy Forest, near Forest Lodge, 38/01.16, on Pinus lignum, 1975, Coppins [2199] E Rose (BM, E).-Germany: Bayern: Allgauer Alpen, 1957, Schoppel E Poelt [Poelt, Lichenes Alpinum no. 56] (H).-Australia: Tasmania: Weindorfers Forest, $41^{\circ} 38^{\prime} \mathrm{S}, 145^{\circ} 56^{\prime} \mathrm{E}, 920 \mathrm{~m}, 1988$, Kantvilas 68/88 (E); Cox Bight, behind west beach, sea-level, 1985, F. A. Elix 20945 (ANUC). Victoria: Bellel Creek, c. $1800 \mathrm{~m}, 5$ vi 1983, M. E. Hale (HO).

Tables. These must be self-explanatory and each presented on separate pages outside the main text. A short title should be provided with any additional information contained in footnotes. Vertical columns should be separated by spacing; vertical lines must be avoided.

Figures. Refer to all drawings, diagrams, graphs and photographs as figures. These should be of the highest quality and suitable for direct reproduction after reduction where appropriate. Each figure should be presented as a separate file. Plan figures to appear within a single column $(67 \mathrm{~mm})$ or for reproduction across two columns $(139 \mathrm{~mm})$.

Drawings, diagrams and graphs. Preferred symbols for graphs are $\boldsymbol{\bullet}, \bigcirc, \boldsymbol{\square}, \square, \boldsymbol{\Delta}, \triangle$; keys to symbols, etc, should be given in figure legends. Tick marks should be placed inside the axes of graphs and the use of greyscales should be avoided.

Photographs (colour or black and white) should be submitted at the size they will appear. Note that there is a charge for colour printing (see Charges below). At the Senior Editor's discretion, images can be published in colour online free of charge while the hard copy appears in black and white, provided that colour is not essential for the interpretation of the paper. In such cases the colour and black and white reproductions must be from the same image file. This facility will be largely restricted to morphological and anatomical images since greyscale graphics are discouraged.

Subdivisions of figures should be labelled with capital letters, e.g. A, B, C, etc. All legends for figures should be provided on a separate page to be included with the text of the paper after the references.

\section{Format for supplying electronic artwork.}

To ensure that your figures are reproduced to the highest possible standards and your article is published as quickly and efficiently as possible, we recommend the following formats and resolutions for supplying electronic figures.

Please ensure that your figures are saved at final publication size and are in our recommended file formats. 
Line artwork (e.g. graphs, drawings histograms, diagrams)

Format: tif or eps

Colour mode: black and white (also known as 1-bit)

Resolution: 1200 dpi

Size: please size to final publication size

\section{Combination artwork (line/tone)}

Format: tif or eps

Colour mode: grayscale (also known as 8-bit)

Resolution: 800 dpi

Size: please size to final publication size

Black and white halftone artwork (e.g. photographs)

Format: tif

Colour mode: grayscale (also known as 8-bit)

Resolution: 300 dpi

Size: please size to final publication size

Colour halftone artwork (e.g. photographs)

Format: tif

Colour mode: CMYK colour

Resolution: $300 \mathrm{dpi}$

Size: please size to final publication size

References. Citations in the text should take the form: Green \& White (2004) or (Brown 1999a, b, 2001; Smith \& Jones 1999). Multiple citations should be ordered chronologically. When papers are by three or more authors, give only the name of the first author followed by et al. (e.g. Halonen et al. 1998) throughout the text. At the end of the text, list the references alphabetically using the following standard forms:

Scherrer, S. \& Honegger, R. (2003) Inter- and intraspecific variation of homologous hydrophobin (H1) gene sequences among Xanthoria spp. (lichenforming ascomycetes). New Phytologist 158: 375389.

Øvstedal, D. O. \& Smith, R. I. L. (2001) Lichens of Antarctica and South Georgia. A Guide to their Identification and Ecology. Cambridge: Cambridge University Press.

Lumbsch, H. T. (2002) Analysis of phenolic products in lichens for identification and taxonomy. In Protocols in Lichenology: Culturing, Biochemistry, Ecophysiology and Use in Biomonitoring (I. Kranner, R. P. Beckett \& A. K. Varma, eds): 281-295. Berlin: Springer.

Muggia, L., Schmitt, I., Blaha, J., Rankl, J. \& Grube, M. (2006) Evolution of polyketide synthases in lichens. In Abstracts of the 8th International Mycological Congress, 21-25 August, 2006, Cairns, Australia, p. 167.

Murtagh, G. J. (1999) Sex and variation in lichen-forming fungi. Ph.D. thesis, University of Nottingham.

References should be listed in alphabetic sequence with: single authors, by date; two authors, alphabetically, then by date; three or more authors by date only. When papers are by more than ten authors, give the names of only the first ten followed by "et al.".
Abbreviations, etc. For guidance on units, symbols, chemical nomenclature and abbreviations consult author guideline for the The New Phytologist.

Copyright. Authors submitting a manuscript do so on the understanding that if it is accepted for publication, copyright in the article, including the right to reproduce the article in all forms and media, shall be assigned exclusively to the British Lichen Society. The Copyright Transfer Agreement, a copy of which is sent with the proofs or can be found on the journal home page listed on the back cover, should be signed by the appropriate person(s) and should accompany the original submission of a manuscript to this journal. The transfer of copyright does not take effect until the manuscript is accepted for publication. Copyright in the paper for the United States of America shall be assigned to the Society. It is the policy of the publisher that authors need not obtain permission in the following cases only: (1) to use their original figures or tables in their future works; (2) to make copies of their papers for use in their classroom teaching; and (3) to include their papers as part of their dissertations.

Offprints. In consideration for the assignment of copyright, the Society will supply 25 offprints and a pdf file of each paper or Short Communication but not of Book Reviews. Further reprints can be ordered at extra cost directly from Cambridge University Press when the author returns the proofs of their article.

Charges. Page charges are not levied. Authors are responsible for the cost of coloured illustrations. However, the Senior Editor is often able to offer a subsidy from British Lichen Society funds to its members who find that they have insufficient money to meet the full cost of colour printing. Authors should consult the Senior Editor regarding current charges and possible subsidies.

Book Reviews. Books dealing with any aspect of lichenology will be reviewed. Publishers wishing to have works reviewed in The Lichenologist should send them to Dr D. J. Hill, Yew Tree Cottage, Yew Tree Lane, Compton Martin, Bristol, BS40 6JS, UK, in the first instance.

Notice: While the Senior Editor and Editors endeavour to check the accuracy of statements in contributions in as far as they are able, it should be emphasized that views expressed in papers in The Lichenologist are those of their authors and do not necessarily represent those of the British Lichen Society, Cambridge University Press, the Senior Editor, or the members of the Editorial Board. 


\title{
BRITISH LICHEN SOCIETY
}

\section{OFFICERS AND CONTACTS 2013}

\author{
President \\ B. P. Hilton, Ph.D., P.G.C.E., F.R.S.A., Beauregard, 5 Alscott Gardens, Alverdiscott, Barnstaple, \\ Devon EX31 3PT \\ Vice President \\ J. M. Simkin, Ph.D., 41 North Road, Ponteland, Newcastle-upon-Tyne, NE20 9UN \\ Secretary \\ C. J. Ellis, Ph.D., Royal Botanic Garden Edinburgh, 20A Inverleith Row, Edinburgh, \\ Lothian EH3 5LR (email: c.ellis@rbge.ac.uk) \\ Treasurer \\ J. F. Skinner, 28 Parkanaur Avenue, Southend-on-Sea, Essex SS1 3HY \\ Assistant Treasurer and Membership Secretary
}

H. Döring, Ph.D., Mycology Section, Royal Botanic Gardens, Kew, Richmond, Surrey TW9 3AB, (email: h.doring@kew.org)

Regional Treasurers

J. W. Hinds, Ph.D., 254 Forest Avenue, Orono, Maine 04473-3202, USA (Americas)

Senior Editor (Lichenologist)

P. D. Crittenden, Ph.D., School of Life Sciences, The University of Nottingham,

University Park, Nottingham NG7 2RD

Editor (Bulletin)

P. F. Cannon, Ph.D., CABI and Royal Botanic Gardens Kew; postal address Royal Botanic Gardens, Kew, Richmond, Surrey TW9 3AB

\section{Conservation Officer}

B. W. Edwards, Dorset Environmental Record Centre, Library Headquarters, Colliton Park, Dorchester, Dorset DT1 1XJ

Mapping Recorder and Archivist

M. R. D. Seaward, D.Sc., F.L.S., F.I.Biol., Department of Environmental Science, The University, Bradford, West Yorkshire BD7 1DP

\section{Librarian}

R. G. Woods, B.Sc., Ty Mawr Mill, Llanfihangel Brynpabuan, Builth Wells, Powys LD2 3SH

Curator

R. K. Brinklow, B.Sc., c/o Dundee Museums and Art Galleries, Albert Square, Dundee DD1 1DA, www.herbarium@britishlichensociety.org.uk

Field Meetings Secretary

S. G. Price, Woodlands, Combs Road, Combs, High Peak, Derbyshire SK23 9UP
Members of Council
J. A. Bailey T. E. Greenaway
C. Gueidan
M. Powell
S. Quin
A. J. Silverside
L. Knight
A. Pentecost

Membership of the British Lichen Society is open to all individuals (not institutions) anywhere in the world interested in any part of lichenology. Subscriptions, due on joining and afterwards on 1 January each year, are: ordinary members, $£ 30$; electronic members, $£ 25$; associate members, $£ 22$; senior associate members, $£ 10$; junior associate members, $£ 5.00$ (US dollar rates are double the sterling rates). Members receive the Bulletin of the British Lichen Society and issues of The Lichenologist published in the year they join, and afterwards while they remain members of the Society, free of charge. Associate members do not receive The Lichenologist. Details of the membership, facilities and activities of the Society and an application form may be found on the British Lichen Society web site at http://www.theBLS.org.uk or obtained from the Membership Secretary (address above). 


\section{The Lichenologist}

Volume 46 Part 1 January 2014

\section{Articles}

GAUSLAA, Y.

ZAMORA, J. C., PÉREZ-ORTEGA, S. and RICO, V. J.

FRYDAY, A. M., PRINTZEN, C. and EKMAN, S.

JAGADEESH RAM, T. A. M.

FERENCOVA, Z., CUBAS, P., DIVAKAR, P. K., MOLINA, M. C. and CRESPO. A.

BARCENAS PEÑA, A., LÜCKING, R., MIRANDA-GONZÁLEZ, R. and HERRERA-CAMPOS, $\mathrm{M}$ de los A.

SEAVEY, F. and SEAVEY, J.

APTROOT, A., FERRARO, L. I. and CÁCERES, M. E. de S.

HÖGNABBA, F., PINO-BODAS, R., Phylogenetic position of the crustose Stereocaulon species NORDIN, A., MYLLYS, L. and STENROOS, S.

APTROOT, A., PARNMEN, S., LÜCKING, R., BALOCH, E., JUNGBLUTH, P., CÁCERES, M. E. S. and LUMBSCH, H. T.

\section{Short Communication}

KUKWA, M., STEPANCHIKOVA, I. S., HIMELBRANT, D. E. and KUZNETSOVA, E. S.
Rain, dew, and humid air as drivers of morphology, function and spatial distribution in epiphytic lichens

Heteroacanthella ellipsospora sp. nov., the first lichenicolous basidiomycete with acanthoid basidia

Bryobilimbia, a new generic name for Lecidea hypnorum and closely related species

The genus Herpothallon (Arthoniaceae) in the Andaman Islands, India

Notoparmelia, a new genus of Parmeliaceae (Ascomycota) based on overlooked reproductive anatomical features, phylogeny and distribution pattern

Three new species of Graphis (Ascomycota: Ostropales: Graphidaceae) from Mexico, with updates to taxonomic key entries for 41 species described between 2009 and 2013

New additions to the lichen genus Enterographa (Roccellaceae) from Everglades National Park including an updated key

New pyrenocarpous lichens from NE Argentina

Molecular phylogeny resolves a taxonomic misunderstanding and places Geisleria close to Absconditella s. str. (Ostropales: Stictidaceae)

The identity of two lichens described by V. P. Savicz from Kamchatka (Russia)

The Lichenologist, Vol. 46, Part 1 was published on 21 January 2014

Cambridge Journals Online

For further information about this journal and

our Open Access option please

go to the journal website at:

journals.cambridge.org/lic
CAMBRIDGE UNIVERSITY PRESS 